\title{
IBADAH RITUAL DALAM MENANAMKAN AKHLAK REMAJA
}

\author{
Kastolani \\ Mahasiswa Program Doktoral Universitas Kebangsaan Malaysia \\ olano2008@yahoo.co.id
}

\begin{abstract}
Abstrak
This article explained what was viewed as ritual worship; pray and fasting to embed noble character. The purpose of worship in Islam are: (a) to strengthen belief and dedication to Allah; (b) to strengthen character, disciplining personality and his role as the agent trusted by Allah on earth; (c) to strengthen friendship and affection among Muslim; (d) to train spiritual and moral. Character occupies crucial role in human's life, as individual as well as society member. It is because the fall and raise of the nation depends on how its society character. The whole of worship system in Islam has close relation with character founding and the performance of ritual worship influences noble character, because good worship performance without having noble character will not useful.
\end{abstract}

Keywords: Worship, Ritual, Character

\begin{abstract}
Abstrak
Artikel ini menjelaskan apa yang dimaksud dengan ibadah ritual yaitu shalat dan puasa dalam menanamkan akhlak mulia. Tujuan ibadah dalam Islam yaitu: (a) Memperkuat keyakinan dan pengabdian kepada Allah. (b) Menguatkan karakter, mendisiplinkan diri dan peranannya sebagai wakil dan hamba yang dipercaya Allah di bumi. (c) Memperkuat tali persaudaraan dan kasih sayang diantara sesama muslim (d) Latihan spiritual dan moral. Kedudukan akhlak dalam kehidupan manusia menempati tempat yang sangat penting sekali, baik sebagai individu maupun sebagai anggota masyarakat. Sebab jatuh bangunya suatu bangsa akan tergantung pada bagaimana akhlak warganya. Seluruh sistem peribadatan dalam Islam mempunyai hubungan yang erat dengan pembinaan akhlak dan pelaksanaan ibadah ritual berpengaruh terhadap akhlak karimah, karena ibadah yang baik tanpa akhlak yang mulia ibadah itu tidak akan berguna
\end{abstract}

Kata Kunci: Ibadah, Ritual, Akhlak

\section{Pendahuluan}

Masa era globalisasi ini, di mana arus informasi semakin terbuka dan hampir tidak mempunyai sekat-sekat yang dapat membatasi atau menyaring materi informasi yang bersifat negatif begitu mudahnya dapat diterima oleh seluruh komponen masyarakat baik masyarakat muda yang didominasi oleh anak-anak dan remaja maupun masyarakat dewasa yang diwakili oeh para pemuda serta tidak ketinggalan oleh masyarakat tua yang didominasi oleh ara orang tua dan lansia. Hal ini adalah berita yang kurang menggembirakan, karena materi-materi yang bersifat negatif dapat mempengaruhi terhadap sikap, moral dn sendi-sendi kehidupan yang telah kokoh dan 
Inject, Interdisciplinary Journal of Communication, Vol. 1, No. 2, Desember 2016:127-144

terbina selama beberapa masa yang mempunyai bobot dan nilai sesuai dengan karakteristik masyarakat yang menjunjung moral yang tinggi, kehormatan serta kebiasaan atau adat yang bijak bagi kehidupan manusia.

Perkembangan industri begitu cepat, didasari pula pola tingkah laku konsumen yang merubah sebagai akibat mengadaptasinya manusia dengan produk-produk industri tersebut, dan ternyata hasilnya adalah kekosongan nilai-nilai apapun yang telah terpatri sejak para utusan dan nabi diturunkan di bumi ini. Nilai-nilai agama yang selalu menjunjung moral, sikap dan kewibawaan manusia justru ditingglakan dan mengambil sikap kebebasan tanpa batas sebagai jalur hidupnya.

Agama yang menjunjung tinggi derajat manusia, seharusnya menjiwai dan mendarah daging bagi seluruh komponen masyarakat. Orang tua atau keluarga seharusnya menanamkan nilai-nilai agama dalam keluarganya masing-masing, hal ini adlah sangat penting untuk menahan pengaruh materi informasi yang negatif yang dapat membahayakan bagi keutuhan sikap, moral dan etika seluruh anggota keluarga. Hal ini seperti ditegaskan dalam al-Quran Surat at-Tahrim ayat 6; Hai orang-orang yang beriman jagalah dirimu dan keluargamu dari api neraka (Soenarjo, 1971:951).

Dari ayat di atas, menegaskan bahwa peran orang tua terhadap anak keluarga tidak bias dikatakan enteng, selain menjaga dirinya, orang tua juga dituntut menjaga sanak saudara kerabat dan keluarganya terutama keturunannya. Oleh karena itu, orang tua sebagi sosok yang sangat berpengaruh dalam keluarga seharusnya membekali diri mereka dengan perbuatan serta gaya yang mencerminkan warna keagamaan agar setiap anggota keluarga dapat terrefleksi sikap dan prilaku orang tua.

Anak sebagai generasi penerus dan melanjutkan keturunan adalah memegang kunci bagi terwarisinya sifat-sifat orang tua dan keluarga. Maka pendidikan dan pola hidup anak tidak bias begitu saja dibiarkan tanpa campur tangan orang tua, dalam hal ini peran orang tua sangat penting bagi pembentukan sikap dan perilaku anak, sebagai mana diungkapkan Kartini Kartono; pola tingkah laku, fikiran dan suges ayah itu dapat mencetak pola yang hampir sama pada anggota-anggota keluarga lainnya (Kartono, 1989:167) 


\section{Ibadah Ritual}

Di dalam Kamus Munjid yang terbit tahun 1986:483, disebutkan ibadah berasal dari akar kata, Abada, Ibadatan, Ubudiyah, yang mempunyai arti mengesakan-Nya, menghormati-Nya, tunduk dan patuh serta taat pada-Nya. Secara harfiah ibadah dapat diartikan sebagai rasa tunduk, atau thaat melaksanakan pengabdian atau tanassuk, merendahkan diri, khudlu, menghinakan diri atau tadzallul dan istikhanah (Muhaimin, 1994:256). Makna ibadah dalam arti yang luas dapat dipahami bertaqarrub atau mendekatkan diri kepada Allah dengan mentaati segala perintah-perintah-Nya, mengamalkan segala yang diizinkan Allah.

Ibadah dapat dibagi menjadi dua yaitu umum dan khusus. Ibadah umum artinya segala amalan yang diizinkan Allah. Sedangkan ibadah yang khusus merupakan apa yang ditetapkan Allah akan perincian-perincian-Nya, tingkah laku dan dengan cara-cara tertentu.

Dari uraian tersebut makna ibadah dapat dipahami sebagai taat yang disertai ketundukan dan kepatuhan kepada Allah SWT., dengan menjalankan segala yang dicintai dan diridhai-Nya, melalui perkataan maupun perbuatan, baik yang bersifat lahiriah maupun yang bersifat batiniah.

Sedang ritual adalah perilaku yang diatur secara ketat yang dilakukan sesuai dengan ketentuan yang berbeda dengan perilaku sehari-hari, baik cara melakukan maupun maknanya (Djamari, 2000:34). Kegiatan ritual dalam Islam, apabila ditinjau dari sudut tingkatan ada tiga, yaitu: (a) Ritual Islam yang primer, adalah ritual yang wajib dilakukan oleh umat Islam. Umpamanya shalat wajib lima waktu sehari semalam. (b) Ritual Islam yang sekunder, adalah ibadah shalat sunnah, misalnya: bacaan dalam ruku' dan sujud, shalat tahajud dan shalat dhuha. (c) Ritual Islam yang tersier, adalah ritual yang berupa anjuran dan tidak sampai pada derajat sunnah (Hakim, 2000:128).

\section{Macam-Macam Ibadah}

Ibadah dibagi menjadi dua macam yaitu: (a) Ibadah mahdhah yaitu hubungan langsung antara hamba dan Tuhannya, yang cara, acara, dan upacaranya telah diatur secara terinci dalam al-Quran dan sunnah Rasul. Dalam fiqih Islam, pembahasan bagian ibadah ini biasanya, meliputi: thaharah, shalat, zakat, shaum, dan hal-hal yang secara langsung berhubungan dengan kelimanya. (b) Ibadah Ghairu Mahdah, yaitu segala amal 
Inject, Interdisciplinary Journal of Communication, Vol. 1, No. 2, Desember 2016:127-144

perbuatan yang titik tolaknya ikhlas, tujuannya mencari ridha Allah dan garis amalnya amal shaleh (Anshari, 1992:85).

Menurut Jalaluddin Rakhmat yang dimaksud dengan ibadah yang pertama bersifat ritual, sedang ibadah yang kedua bersifat sosial. Untuk tidak mengacaukan orang awam, para fuqaha menyebut ibadah pertama adalah ibadah mahdhah dan ibadah kedua lazim disebut mua'malah" (Rahmat, 1986:138).

Keutamaan ibadah dalam Islam bebas dari segala perantara, Islam telah melepaskan ibadah dari ikatan perantara yang menghubungkan manusia dengan Sang Maha Pencipta. Para ulama bukan perantara yang menghubungkan manusia dengan Tuhan, atau mereka juga tidak memiliki hak untuk menerima ataupun menolak peribadatan yang ditujukan kepada Tuhan. Di dalam pandangan Islam, para ulama tersebut hanyalah manusia yang memiliki fungsi tambahan untuk menuntun mereka yang tidak berpengetahuan.

Dalam Islam, kewajiban tersebut merupakan kewajiban bagi mereka yang memiliki kelebihan ilmu. Dengan kata lain Islam tidak membenarkan adanya dominasi ulama terhadap kehidupan para pemeluknya tidak ditujukan untuk wilayah tertentu, Islam tidak saja membebaskan peribadatan manusia dari belenggu perantara, tetapi ia juga membebaskan dari keterikatan terhadap tempat tertentu. Islam memandang seluruh tempat bahkan di punggung hewan sekalipun, dan tentu saja masjid yang sengaja dibangun untuk melaksanakan ibadah, merupakan tempat yang layak untuk beribadah.

Di mana saja seorang manusia akan selalu dapat menghadapkan wajahnya kepada Tuhannya melingkupi segala, ibadah dalam Islam tidak hanya terpaku pada bentuk-bentuk doa atau pujian tertentu yang harus diucapkan atau dilaksanakan pada waktu-waktu tertentu saja. Islam berpandangan bahwa segala perbuatan baik yang dilaksanakan dengan tulus serta kesadaran bahwa yang dilaksanakan karena perintah Tuhan serta semata-mata untuk mencari keridhaan-Nya, maka hal tersebut merupakan ibadah dan untuk itu ia akan mendapatkan pahala dari-Nya (Ahmad, 1989:47).

\section{Pelaksanaan Ibadah Ritual}

Adapun yang dimaksud ibadah ritual di sini adalah shalat dan puasa. (a) Shalat, menurut bahasa shalat artinya doa, (Munawir, 1984:847) yang berasal dari akar kata salla-yusalli yang artinya mendoakan (Abdurrahman, 1992:1). Kemudian shalat 
merupakan fardhu'ain bagi tiap-tiap muslim yang telah baligh. Kewajiban shalat ini dengan tegas diperintahkan oleh Allah dalam surat an-Nisa ayat 103 yang artinya maka dirikanlah shalat itu atau sebagaimana biasa, sesungguhnya shalat itu adalah fardhu yang ditentukan waktunya atas orang-orang yang beriman.

Menurut Imam Taqiyyudin shalat diartikan sebagai (dalam Abi Bakar, tt:82) suatu pernyataan dari beberapa ucapan dan perbuatan yang diawali dengan bacaan takbir dan diakhiri dengan salam menurut beberapa syarat. Dan menurut istilah berarti suatu sistem ibadah yang tersusun dari beberapa perkataan dan laku perbuatan yang dimulai dengan takbir dan diakhiri dengan salam, berdasar atas syarat-syarat dan rukunrukun tertentu (Razak, 1993:178). Dari beberapa pengertian di atas, nampak bahwa pengertian tersebut menggambarkan arti shalat secara lahir saja, hal ini dimaksudkan untuk mempermudah pengertian dan pemahaman shalat itu sendiri.

Adapun pengertian shalat yang menggambarkan jiwa atau hakekat shalat adalah (Ash-Shiddieqy, 1983:64) jiwa shalat adalah menghadap Allah dengan penuh jiwa yang khusyu dihadapan-Nya dan berikhlas bagi-Nya serta hadir hati dalam berdzikir, berdoa dan memuji. Dengan demikian dapat disimpulkan bahwa shalat adalah menghadapkan hati atau jiwa kepada Allah dengan penuh khusyu, ikhlas dalam sebuah bentuk ibadah yang terdiri atas beberapa perkataan dan perbuatan, diawali dengan takbir dan diakhiri dengan salam dengan memenuhi syarat dan rukun tertentu. Selain sebagai kewajiban, shalat juga berfungsi sebagai sarana pembina akhlak yang efektif. Orang yang mengerjakan shalat tetapi shalatnya itu tidak membekas pada aktivitas sehari-hari, shalatnya itu tidak ada nilainya dan membuat ia bertambah jauh dari Allah.

Selain shalat wajib lima waktu, ada juga shalat lain yang wajib diketahui, yaitu: (a) Shalat sunnah rawatib, yaitu shalat yang dilakukan sebelum atau sesudah shalat fardhu yang dilakukan sendiri atau munfarid, antara lain dua rakaat sebelum subuh, dua atau empat rakaat sebelum dan atau sesudah dhuhur, dua rakaat sesudah maghrib, dan dua rakaat sesudah isya. (b) Shalatullail, yaitu shalat di waktu malam, yang terdiri dari shalat tahajud, shalat tarawih pada bulan Ramadhan dan shalat witir. (c) Shalat sunnah yang lain seperti shalat hajat, shalat dhuha, shalat istikharah, shalat istisqa, dan lain-lain.

Puasa menurut bahasa puasa berarti imsak atau menahan, berpantang atau meninggalkan (Daradjat, 1999:240). Sedang menurut istilah syara ialah (Rachim, 1987:188) yang artinya menahan diri dari makanan, minuman dan senggama disertai 
Inject, Interdisciplinary Journal of Communication, Vol. 1, No. 2, Desember 2016:127-144

dengan niat, sejak dari terbit fajar sampai terbenam matahari disertai niat dan beberapa syarat (Rasyid, 2000:220). Dasar yang mewajibkan berpuasa telah dijelaskan dalam al-Quran, yaitu surat al-Baqarah, ayat 183 yang artinya hai orang-orang yang beriman, diwajibkan atas kamu berpuasa sebagaimana diwajibkan atas orang-orang sebelum kamu agar kamu bertaqwa.

Selain puasa wajib di bulan Ramadhan, ada puasa-puasa lain yang dapat diketahui yaitu (a) Puasa sunnah, antara lain: puasa senin dan kamis, enam hari pada bulan Syawal, 10 Muharram dan tiap tanggal tiga belas, empat belas dan limabelas Qomariah. (b) Puasa makruh, yaitu puasa dalam keadaan sakit dan puasa sunnat pada hari Jum'at atau hari Sabtu saja. (c) Puasa haram, puasa yang dilakukan terus-menerus, puasa hari tasyrik dan puasanya wanita yang sedang haid dan nifas (Daradjat, 1993:58).

Dilihat dari segi penampilan, maka puasa merupakan amalan batin yang membutuhkan kesabaran dan keikhlasan semata, apabila dilaksanakan dengan sepenuhnya tentu akan membentuk kepribadian seseorang lebih sempurna di samping akan mendapat ridha dari Allah, sebab puasa melatih jiwa agar bersih dari perbuatan dosa dan untuk melaksanakan perintah Allah.

Menurut Sudarsono, hikmah puasa antara lain; (a) Menahan sifat sabar, karena orang yang berpuasa terdidiklah menahan kelaparan, kahausan dan keinginan, tentulah akan berhati sabar menahan segala kesukaran. (b) Timbul suatu sifat atau perasaan ingin membantu fakir miskin (c) Mendidik bersifat amanah, karena dengan puasa orang dapat melatih dirinya agar menjadi kepercayaan orang. (d) Mendidik dari sifat shiddiq, karena dengan puasa orang dapat menghindarkan dirinya dari sifat pendusta (pembohong). (e) Menjaga kesehatan badan serta dapat merasakan kenikmatan yang sebenarnya atas pemberian Allah (Sudarsono, 1994:96).

\section{Tujuan Ibadah Ritual dan Akhlak Remaja}

Meskipun tujuan peribadatan adalah untuk mengingat dan memuliakan Allah SWT, namun perlu ditekankan bahwa kemuliaan dan keagungan Allah tidak bergantung sedikitpun pada pemuliaan dan pengakuan makhluk-Nya, karena Dia tidak bergantung pada ciptaan-Nya dan bebas dari segala kebutuhan, tetapi manusia membutuhkan bentuk-bentuk peribadatan yang berulang untuk menjaga hubungan dengan Tuhannya. 
Adapun tujuan ibadah dalam Islam yaitu; (a) Untuk memperkuat keyakinan dan pengabdian kepada Allah. (b) Untuk menguatkan karakter, mendisiplinkan diri dan peranannya sebagai wakil dan hamba yang dipercaya Allah di bumi. (c) Untuk memperkuat tali persaudaraan dan kasih sayang diantara sesama muslim (Haneef, 1979:46) (d) Di samping latihan spiritual, juga merupakan latihan moral (Nasution, 1985:40).

Perkataan akhlak berasal dari bahasa Arab jamak dari khuluqun yang menurut lughat diartikan budi pekerti, perangai, tingkah laku atau tabiat (Yakub, 1993:11). Menurut Ahmad Amin, beliau mengemukakan bahwa akhlak adalah kebiasaan kehendak (Amin, 1975:62). Ini berarti bahwa kehendak itu bila dibiasakan akan sesuatu kebiasaannya itu disebut akhlak, misalnya bila kehendak itu dibiasakan memberi maka kebiasaan itu disebut akhlak dermawan. Sedangkan menurut Imam al-Ghazali, akhlak adalah sesuatu sifat yang tertanam dalam jiwa yang dari padanya timbul perbuatan dengan mudah tanpa memerlukan pertimbangan pikiran terlebih dahulu (Ghazali, tt:52). Sedangkan menurut Elizabeth H Hurlock, mengemukakan sebagai berikut:

Behavior which may be called "true morality" not only conforms to social standards but also is carried out voluntarily. It comes with the transition from external to internal authority and consists of conduct regulated from within". Artinya: Tingkah laku atau yang dikenal dengan moral yang baik, bukan hanya merupakan aturan kemasyarakatan saja, tetapi yang lebih penting harus dilaksanakan secara suka rela. Tingkah laku tersebut dapat dilihat dari luar yang digerakkan oleh sebuah kekuatan yang diatur dari dalam" (Hurlock, tt:386).

Dari beberapa pengertian akhlak yang dikemukakan oleh para ahli, maka dapat dipahami bahwa akhlak adalah suatu kekuatan yang timbul dari dalam jiwa atau diri yang tercermin dari tingkah laku lahir tanpa memerlukan pertimbangan terlebih dahulu, yang dalam pelaksanaannya sudah menjadi kebiasaan. Apabila perbuatan spontan itu baik menurut akal maka itu disebut dengan akhlak yang baik, dan sebaliknya, bila tidak sesuai dengan akal maka disebut dengan akhlak yang tercela.

Remaja adalah mereka yang telah meninggalkan masa kanak-kanak yang penuh dengan ketergantungan dan meuju masa pembentukan tanggung jawab. Masa remaja ini ditandai dengan pengalaman-pengalaman yang baru yang sebelumnya belum pernah terbayangkan, baik fisik biologisnya maupun psikis (Basri, 2000:4). 
Inject, Interdisciplinary Journal of Communication, Vol. 1, No. 2, Desember 2016:127-144

Dan secara psikologis ketaatan dan ketekunan beribadah hampir tidak pernah dicapai oleh masa remaja tanpa bimbingan dan keteladanan dari orang tua, para pendidik di sekolah, dan para pemimpin di tengah-tengah masyarakat (Sudarsono, 1995:161).

Mengenai seberapa panjang masa remaja, para ahli jiwa tidak mempunyai kata sepakat. Mereka hanya sepakat dalam menentukan masa remaja, yaitu dengan dimulainya kegoncangan yang ditandai dengan datangnya haid pertama pada wanita dan mimpi pada pria. Kejadian yang menentukan ini tidak sama antara satu anak dengan anak yang lainnya, ada yang mulai 12 tahun dan ada pula yang sesudah tigabelas tahun. Namun pada umumnya para ahli mengambil patokan antara tigabelas sampai duapuluh satu tahun (Daradjat, 1993:71).

Kegoncangan kepribadian yang dialami remaja terlihat pula dalam peribadatannya. Ibadahnya secara berganti-ganti ditentukan oleh sikap yang ada dalam dirinya. keadaan jasmaniah yang terganggu menyebabkan ketidaktenangan pada diri remaja. Ia sering tidak tahu sendiri apa kemauannya. Jika hari ini ia ingin melakukan sesuatu, esoknya ia akan berpaling kepada hal lain. Kelabilan ini terlihat dalam lapangan peribadatannya. Kalau hari ini ia ingin shalat dengan khusyu, esoknya ia tidak shalat lagi.

Remaja dapat menjadi seorang yang kelihatan paling beragama dengan melaksanakan ibadah yang interaktif, seperti: berpuasa berhari-hari, membaca al-Quran berjam-jam dan berdoa setiap malam. Hal ini dimungkinkan dorongan hidup yang tinggi dan memungkinkan pengalaman ketuhanan yang mendalam, semacam pertobatan, tetapi dapat pula remaja menjadi orang yang menghindari peribadatan. Ia menolak pengikatan norma-norma agama, menolak kewajiban-kewajiban agama dan justru mencoba melanggar laranga agama (Ahyadi, 1987:47).

Jadi sering terlihat kesibukan beribadah yang berlebihan yang mudah berubah menjadi sikap acuh tak acuh terhadap ibadah disamping keinginan yang kuat untuk beribadah, terlihat pula keinginan yang besar untuk mengalami bermacam-macam, termasuk penagalaman keagamaan. Ia mencoba mempraktekkannya dan mengamalkannya dalam peribadatan.

Akhlak bersumber dari al-Quran dan Sunnah sebagai penjelasnya dan manusia dilengkapi dengan suara hati atau instink untuk mengarahkan perbuatannya. Akhlak tercermin dari tujuan diutusnya Nabi Muhammad SAW menjadi Nabi dan Rasul, 
sebagai tauladan yang harus dianut oleh umatnya, sebagaimana firman Allah dalam surat al-Ahzab ayat 21 yang artinya sesungguhya telah ada pada diri Rasulullah itu suri tauladan yang baik bagimu (yaitu) bagi orang yang berharap (rahmat Allah) dan (kedatangan) hari kiamat dan banyak menyebut Allah. Sebagai tauladan, Rasulullah telah dibekali akhlak yang mulia. Hal ini berdasarkan firman Allah dalam surat al-Qalam ayat 4: yang artinya, dan sesungguhnya kamu benar-benar berbudi pekerti yang agung.

Dalam sejarah dunia diakui bahwa Rasulullah seorang pemimpin yang tiada bandingannya, maka etika yang baik adalah yang dilaksanakan oleh Rasulullah sendiri. Hadist sebagai dasar dari akhlak dapat diketahui dari diutusnya Nabi Muhammad SAW, yaitu untuk menyempurnakan akhlak, sebagaimana disebutkan dalam hadist (Imam Ahmad, tt:323): Artinya dari Abi Hurairah r.a berkata: bahwa Rasullulah SAW bersabda Aku diutus untuk menyempurnakan akhlak yang bagus"(H.R.Bukhari).

Selain berdasar dari al-Quran dan hadist di atas, Islam mengakui adanya kekuatan instink yang merupakan hati nurani yang menilai sesuatu itu patut atau tidaknya, seperti yang tercantum dalam suatu hadist Nabi yang berbunyi yang artinya dari An-Nawwas bin Sam'an r.a. berkata: Saya menanyakan tentang kebajikan dan dosa (kejahatan) kepada Rasulullah SAW, kemudian beliau menjawab: "Kebajikan itu adalah budi pekerti yang baik dan dosa (kejahatan) itu adalah sesuatu yang merisaukan hatimu dan kamu tidak senang bila hal itu diketahui orang lain (Shabir, 1981:52).

Jadi, di dalam jiwa manusia itu ada kekuatan yang bisa menilai apakah perbuatan itu baik apabila dikerjakan sehingga menjadi budi pekerti yang mulia dan apabila mengerjakan sesuatu pekerjaan yang tidak baik, dia merasa malu dan tidak senang apabila perbuatannya itu diketahui oleh orang lain. Dengan demikian akhlak bersumber dari al-Quran, Sunnah dan juga suara hati manusia sendiri yang dapat menilai apakah perbuatan itu baik atau tidak.

\section{Macam-Macam Akhlak}

Secara teoritik, akhlak dapat dibedakan menjadi dua, yakni akhlak mahmudah dan akhlak madzmumah. Akhlak mahmudah adalah akhlak yang sejalan dengan al-Quran dan sunnah, sedangkan akhlak madzmumah adalah perbuatan yang melanggar aturan yang ditentukan oleh Allah dan Rasulnya (Atang, 2000:200). 
Inject, Interdisciplinary Journal of Communication, Vol. 1, No. 2, Desember 2016:127-144

Di samping itu, akhlak yang dianjurkan oleh Islam meliputi hubungan dengan Allah dan hubungan sesama makhluk yaitu kehidupan individu, keluarga, masyarakat, bangsa dan makhluk hidup lainnya seperti: hewan, tumbuh-tumbuhan, alam sekitar dan sebagainya. Sehubungan dengan hal tersebut di atas mengenai akhlak yang berhubungan dengan manusia, diantaranya adalah akhlak terhadap orang yang lebih tua, akhlak terhadap teman sebaya dan akhlak terhadap orang yang lebih muda.

Akhlak terhadap orang yang lebih tua yaitu diantara orang yang lebih tua dari kita adalah ibu dan ayah, mereka sangat berjasa dan mempunyai tanggung jawab yang besar terhadap anaknya. Seorang anak menurut ajaran Islam diwajibkan berbuat baik kepada orang tuanya dalam keadaan bagaimanapun. Hal ini dinyatakan Allah dalam surat al-Isra ayat 23: yang artinya "Dan Tuhanmu telah memerintahkan supaya kamu jangan menyembah selain Dia dan hendaklah kamu berbuat baik pada ibu bapakmu dengan sebaik-baiknya.

Jika salah seorang diantara keduanya atau kedua-duanya sampai umur lanjut dalam pemeliharaanmu, maka sekali-kali janganlah kamu mengatakan kepada keduanya perkataan "ah" dan janganlah kamu membentak mereka dan ucapkan kepada mereka perkataan yang mulia". Berbuat baik kepada orang tua tidak hanya terbatas ketika mereka masih hidup, tetapi terus berlangsung walaupun mereka telah meninggal dunia dengan cara mendo'akan memintaampunan untuk mereka. Menepati janji mereka yang belum terpenuhi dan meneruskan silaturahmi dengan sahabat-sahabat mereka ketika masih hidup (Daradjat, 1980:33).

Akhlak terhadap orang yang sebaya, orang yang sebaya disebut juga dengan teman. Teman ada yang bermacam-macam, ada teman yang senasib sepenanggungan, merasakan susah apabila temannya susah dan ikut merasa senang apabila temannya senang. Adapun teman yang terjadi di waktu senang atau karena menderita suatu nasib yang sama. Tetapi apabila dia dalam keadaan senang selalu ada, sedang dalam keadaan susah dia tidak peduli, itu bukan teman yang sejati. Karena itu, kalau berteman hendaklah memilih teman yang bakal memberi manfaat bagi kita. Kewajiban kepada teman yang utama adalah membimbing dan memberikan pengaruh yang baik, agar kita tetap berakhlakul karimah. Selain itu manusia juga mendapatkan pengaruh yang baik darinya. Dan kita pun berharap mendapatkan kontrol dari teman yang baik, yang dapat memperingatkan kalau manusia berbuat salah sehingga dapat saling nasehat menasehati 
untuk kebenaran. Hal ini berdasar firman Allah dalam surat al-Asr ayat 1-3 yang artinya Demi masa. Sesungguhnya manusia itu benar-benar berada dalam kerugian. Kecuali orang-orang yang yang beriman dan mngerjakan amal shaleh dan nasehat menasehati supaya menetapi kesabaran.

Akhlak terhadap yang lebih muda, bergaul di rumah dan di luar rumah, remaja akan selalu bertemu dengan orang yang lebih tua dan yang lebih muda. Dengan yang lebih muda, remaja harus menyayangi. Pengertian yang tua terhadap yang muda, secara harfiah berarti yang tua umurnya terhadap yang muda umurnya. Kewajiban kakak terhadap adik, kewajiban orangtua tarhadap anak-anaknya. Orang yang lebih tua harus menyayangi yang lebih muda dengan membimbing, memberi pendidikan, memberi pelajaran, menolong memenui kebutuhannya dan membimbing menyelesaiakan persoalannya.

\section{Faktor-faktor yang mempengaruhi Akhlak.}

Manusia merupakan makhluk yang paling sempurna bila dibandingkan dengan makhluk yang lainnya, karena dalam diri manusia terdapat kemampuan yang tidak dimiliki oleh makhluk lainnya, ia mempunyai akal sebagai pembeda dengan yang lain. Akibat adanya kemampuan inilah menusia mengalami perkembangan dan perubahan baik dari segi psikologis maupun fisiologis. Perubahan yang terjadi pada diri manusia akan menimbulkan perubahan terhadap perkembangan pribadi manusia atau tingkah lakunya yang dipengaruhi oleh banyak faktor.

Akhlak tidak dapat dipisahkan dari mental seseorang, sebab akhlak seseorang merupakan pencerminan dari pada mentalnya. Kita tidak dapat mengetahui mental seseorang, melainkan yang dapat diketahui adalah akhlaknya yang merupakan pekerti, sikap, tingkahlakunya dan kebiasaan sehari-hari. Dengan mengetahui akhlaknya yang merupakan hal yang lahiriyah tersebut kita dapat mengetahuinya mentalnya.

Para ahli ilmu jiwa menerangkan bahwa mental seseorang dibentuk oleh segala pengalaman yang sampai kepadanya, mulai ia terbentuk menjadi manusia selama hidupnya. Menurut Zakiah Daradjat menerangkan bahwa pembinaan mental seseorang mulai sejak kecil, semua pengalaman yang dilalui, baik yang disadari atau tidak, ikut menjadi unsur-unsur yang menggabung dalam kepribadian seseorang. Diantara unsur- 
Inject, Interdisciplinary Journal of Communication, Vol. 1, No. 2, Desember 2016:127-144

unsur terpenting yang akan menentukan corak dikemudian hari adalah nilai-nilai yang diambil dari lingkungan, terutama keluarga sendiri (Daradjat, 1980:13).

Oleh karena itu para ahli etika berpendapat bahwa sumber-sumber akhlak yang merupakan pembentukan mental itu ada dua faktor, yaitu: faktor intern dan faktor ekstern. Berdasarkan pendapat di atas dapat diambil suatu kesimpulan bahwa perkembangan dan perubahan akhlak pada manusia dipengaruhi oleh dua faktor, yaitu: (a) Faktor Internal, bahwa menusia diberi kebebasan memilih antara dua jalan, yaitu jalan kefasikan dan ketakwaan, apabila ia ingin selamat, maka jalan ketakwaan yang ditempuh begitu pula sebaliknya. Faktor-faktor yang terdapat dalam diri manusia itu adalah instink atau naluri, kebiasaan, kemauan dan suara batin. (b) Faktor Eksternal yaitu selain dari faktor intern manusia juga dipengaruhi oleh faktor dari luar, misalnya pengalaman pada masa kecil, khususnya dari lingkungan keluarga; bagaimana cara orang tua mempengaruhi anak, pengaruh kelas sosial, berbagai lembaga sosial anak dan berbagai kelompok teman (Najati, 1981:241). Faktor-faktor itu antara lain lingkungan keluarga, masyarakat dan teman sebaya. (c) Lingkungan keluarga, keluarga merupakan lingkungan yang terdekat untuk membesarkan, mendewasakan dan didalamnya anak mendapat pendidikan yang pertama.

Oleh karena itu, keluarga memiliki peranan yang penting dalam perkembangan anak, keluarga yang baik akan berpengaruh positif terhadap perkembangan anak sedang keluarga yang jelek akan berpengaruh negative (Sudarsono, 1995:165). Dalam mengembangkan akhlak anak, peranan orang tua sangatlah penting, terutama pada waktu anak masih kecil. Semua faktor-faktor tersebut di atas menggabung menjadi satu membentuk akhlak seseorang. Mana yang lebih kuat, lebih banyak memberi corak akhlaknya. Dengan demikian untuk pembentukan akhlak yang baik agar setiap insan mempunyai akhlak yang mulia, tidak hanya dipengaruhi oleh satu faktor saja, melainkan harus dari segala arah dari mana sumber-sumber akhlak itu datang.

Kedudukan akhlak dalam kehidupan manusia menempati tempat yang sangat penting sekali, baik sebagai individu maupun sebagai anggota masyarakat. Sebab jatuh bangunya suatu bangsa akan tergantung pada bagaimana akhlak warganya. Seorang yang berakhlak mulia, selalu melaksanakan kewajiban-kewajibannya, memberikan hak yang harus diberikan kepada yang berhak. Kewajiban terhadap dirinya sendiri, terhadap Tuhannya, terhadap manusia maupun terhadap alam sekitarnya. Dia akan menempati 
martabat yang mulia dalam pandangan umum, walaupun secara materi keadaannya sangat sederhana. Dan sebaliknya seseorang yang berakhlak buruk, yang dalam masyarakat sering disebut tidak berakhlak, tidak melaksanakan kewajiban dan tidak memberikan hak kepada yang mempunyainya. Yang demikian ini seperti halnya anggota tubuh terkena penyakit, maka seluruh badan merasakan sakit.

\section{Implikasi Ibadah Ritual pada Akhlak}

Seluruh sistem peribadatan dalam Islam mempunyai hubungan yang erat dengan pembinaan akhlak. Sikap mental positif dan keluhuran akhlak adalah konsekuensi dari ibadah yang sempurna. Ibadah harus dijiwai dan dilengkapi dengan akhlak yang mulia. Shalat adalah pekerjaan hamba yang beriman dalam situasi menghadapkan wajah dan sukmanya kepada Zat Yang Maha Suci. Maka manakala shalat itu dilakukan secara tekun dan kontinu, menjadi alat pendidikan rohani manusia yang efektif, memperbaharui dan memelihara jiwa serta memupuk pertumbuhan kesadaran.

Makin banyak shalat itu dilakukan dengan kesadaran bukan dengan paksaan dan tekanan apapun, berarti sebanyak itu rohani dan jasmani dilatih beribadah kepada Allah SWT. Efeknya membawa kepada kesucian rohani dan jasmani. Kesucian rohani dan jasmani akan memancarkan akhlak yang mulia, sikap hidup yang dinamis penuh amal shaleh.

Dengan demikian hikmah-hikmah yang terkandung di dalam pelaksanaan shalat adalah (a) Menjaga kesucian, baik dari segi fisik maupun dalam keadaan bersih dari najis dan suci dari hadats, baik hadats besar maupun hadats kecil. Bukan badan saja yang harus suci, melainkan pakaian serta tempat shalat. Setelah bersuci, baru dimulai shalat itu. Hal ini memberi arti bahwa sebelum memulai pekerjaan dan umat Islam membersihkan diri, jasmani dan rohani. Jadi hidup seorang muslim dimulai dengan mengisi kesucian dan nafas tauhid, sehingga hidup itu bertenaga dan optimis. (b) Dianjurkan dengan berjamaah, dalam pelaksanaan shalat sangat dianjurkan dengan berjamaah, karena memiliki derajat yang lebih baik pahalanya dibanding dengan shalat sendirian. Hal ini mendidik pemeluk-pemeluknya bergaul, bermasyarakat, mempertebal ikatan ukhuwah islamiyah.

Untuk melaksanakan jamaah perlu tempat, oleh karena itu Masjid dibangun. Sistem jamaah di Masjid mengandung nilai-nilai yang penting. Ia mendidik manusia 
Inject, Interdisciplinary Journal of Communication, Vol. 1, No. 2, Desember 2016:127-144

menumbuhkan silaturahmi atau solidaritas sosial yang kuat dan ajaran persaudaraan antarmanusia. Anggota-anggota jamaah duduk dalam satu barisan, yang miskin berdampingan dengan yang kaya. Semuanya sama-sama melakukan gerakan-gerakan yang serupa dan seirama. Dan shalat ditutup dengan salam, artinya saling menyatakan selamat, sejahtera dan damai. (c) Dilaksanakan dengan penuh kekhusyuan, maksudnya suasana menyejukkan jiwa dan dikatakan sebagai rohnya shalat. Shalat tanpa khusyu ibarat tanpa roh. Untuk khusyu seutuhnya memang sulit, tetapi kita berusaha terus untuk meningkatkan kekhusyukan itu. Di antara langkah-langkah praktis untuk ini adalah dengan memilih tempat dan suasana yang mendukung, mengosongkan pikiran dari segala masalah yang dihadapi ketika akan menunaikan shalat, memahami arti dan makna yang dibaca, membaca bacaannya dengan terdengar oleh telinga sendiri dan melaksanakannya dengan berjamaah. (d) Diwajibkan menutup aurat, menutupi aurat mengandung beberapa hikmah dan rahasia yang dalam, diantaranya menyatakan manusia malu berhadapan dengan Allah SWT dalam keadaan yang tidak pantas atau terbuka auratnya. Apabila merasa tidak pantas berhadapan dengan orang biasa dalam keadaan tidak tertutup aurat, maka tentulah kita harus berperasaan kepada Tuhan semesta alam dan supaya tidak mudah merangsang syahwat (Razak, 1993:180).

Melihat hikmah yang demikian besar yang terkandung dalam ibadah shalat adalah wajar apabila Nabi harus mi'raj ke langit menghadap Allah. Shalat adalah satusatunya ibadah yang diterima langsung dari Tuhan, sedang kewajiban-kewajiban yang lainnya cukup melalui wahyu yang disampaikan oleh Malaikat Jibril.

Demikian pula dengan ibadah puasa banyak mengandung bagi pemantapan nilainilai akhlak ke dalam mentalitas dan sikap hidup muslim. Bagi yang melakukan kewajiban puasa dengan ikhlas, tentu mereka dapat dikatakan telah membuktikan imannya kepada Tuhan. Karena iman itu bukan saja diucapkan dengan lidah, tetapi harus pula diikrarkan dengan kalbu kemudian dibuktikan dalam perbuatan.

Diantara hikmah-hikmah puasa adalah sebagai berikut: (a) Manfaat bagi jiwa, berbagai macam latihan mental yang ditempakan oleh puasa. Ia mendidik manusia berjiwa besar, sanggup mengatasi segala macam kesulitan dan cobaan hidup. Ia menumbuhkan sifat sabar pada manusia, sabar dalam menerima kesusahan, sabar dalam menahan diri dari berbuat maksiat dan sabar dalam menghadapi bencana yang menimpa dengan penuh ketabahan. (b) Menjaga dari perkataan kotor, sebagaimana arti 
kata puasa dalam bahasa Arab: shaumun, artinya menahan dari segala sesuatu yang buruk, maka berdasar dari kata asalnya, Nabi telah meletakkan nilai yang sebenarnya tentang puasa. Puasa bukan hanya menahan diri dari makan, minum, tetapi juga wajib baginya tidak berkata kotor dan berbuat sesuatu yang sia-sia.Yang dimaksud dengan perkataan kotor adalah segala perkataan yang negatif, berbahaya dan merugikan. Dan perbuatan yang sia-sia adalah perbuatan yang tidak bermanfaat dan tidak ada gunanya. (c) Menjaga dari tingkah laku yang buruk, dengan berpuasa manusia dididik untuk berbuat yang baik dan mulia, karena perbuatan yang sifatnya kemungkaran dan maksiat dapat membatalkan puasa tersebut, sehingga dengan berpuasa setiap manusia dapat mengubah dan melengkapi akhlak di dalam kehidupannya kepada tingkat yang lebih baik. (d) Mempunyai nilai sosial yang tinggi, rasa lapar dan dahaga akibat puasa menanamkan jiwa sosial yang kuat. Puasa mengajarkan pengalaman, sebagaimana nasib kaum dhuafa yang siang-malam hanya menghadapi problem perut. Hal ini dapat menggugah rasa santun, kasih sayang, kedermawaan dan kepekaan sosial. Sebagai realisasi dari latihan ini, maka setiap kepala diwajibkan membayar zakat fitrah sebanyak dua koma lima kilo gram beras pada akhir bulan Ramadhan untuk dibagi-bagikan kepada fakir miskin (Razak, 1993:204).

Selain zakat juga memberikan buka puasa. Kesempurnaan puasa bukan hanya menahan diri dari makan, minum dan bersetubuh pada siang hari saja, akan tetapi mengandung arti menahan diri dari segala perbuatan yang tidak sesuai dengan hikmah dan tujuan puasa. Shalat dan bentuk ibadah yang lain, seperti puasa dan haji, bersangkutan kuat sekali dengan keteguhan jiwa dan ketabahan hati menempuh hidup, karena adanya harapan kepada Tuhan. Sedangkan harapan kepada Tuhan itu sendiri adalah merupakan salah satu makna iman, yang antara lain melahirkan rasa aman.

Kemudian rasa aman yang terlindung oleh Tuhan itu akan menjadi bekal mewujudkan cita-cita menempuh hidup bermoral, yaitu hidup yang disemangati oleh kesadaran sosial yang setinggi-tingginya. Kesadaran sosial itu, misalnya dilambangkan oleh ucapan salam diakhir shalat dengan menengok kanan-kiri. Sebagaimana yang telah dikemukakan di atas, ibadah yang tidak melahirkan kesadaran sosial itu akan kehilangan maknanya yang hakiki, sehingga pelaku suatu bentuk ibadah formal tanpa kesadaran sosial itu justru terkutuk oleh Tuhan (Madjid, 2000:67). 
Inject, Interdisciplinary Journal of Communication, Vol. 1, No. 2, Desember 2016:127-144

\section{Simpulan}

Ibadah dapat dibagi menjadi dua yaitu umum dan khusus. Ibadah umum artinya segala amalan yang diizinkan Allah. Sedangkan ibadah yang khusus merupakan apa yang ditetapkan Allah akan perincian-perincian-Nya, tingkah laku dan dengan cara-cara tertentu. Dari uraian tersebut makna ibadah dapat dipahami sebagai taat yang disertai ketundukan dan kepatuhan kepada Allah SWT., dengan menjalankan segala yang dicintai dan diridhai-Nya, melalui perkataan maupun perbuatan, baik yang bersifat lahiriah maupun yang bersifat batiniah. Sedang ritual adalah perilaku yang diatur secara ketat yang dilakukan sesuai dengan ketentuan yang berbeda dengan perilaku sehari-hari, baik cara melakukan maupun maknanya

Dari uraian di atas dapat dipahami bahwa pelaksanaan ibadah ritual berpengaruh terhadap akhlak karimah, karena ibadah yang baik tanpa akhlak yang mulia ibadah itu tidak akan berguna. Dan sebaliknya, akhlak yang baik tanpa pengamalan ibadah belum bisa dikatakan iman yang sempurna.

Ibadah ritual merupakan ibadah yang dengannya seorang hamba berhubungan langsung dengan Allah. Disamping itu tata cara ibadah ritual telah diatur secara terperinci dalam al-Quran maupun Sunnah Nabi, yang tercakup dalam ibadah ritual ini, misalnya shalat dan puasa. Selain merupakan kewajiban, ibadah adalah sarana yang efektif untuk dapat mendekatkan diri kepada Allah. Akhlak adalah suatu kekuatan yang timbul dari dalam jiwa atau diri yang tercermin dari tingkah laku lahir tanpa memerlukan pertimbangan terlebih dahulu, yang dalam pelaksanaannya sudah menjadi kebiasaan. Apabila perbuatan spontan itu baik menurut agama dan akal maka itu disebut akhlak yang baik, dan begitu pula sebaliknya.

Kedudukan akhlak dalam kehidupan manusia menempati tempat yang sangat penting sekali, baik sebagai individu maupun sebagai anggota masyarakat. Sebab jatuh bangunya suatu bangsa akan tergantung pada bagaimana akhlak warganya. Seorang yang berakhlak mulia, selalu melaksanakan kewajiban-kewajibannya, memberikan hak yang harus diberikan kepada yang berhak. Kewajiban terhadap dirinya sendiri, terhadap Tuhannya, terhadap manusia maupun terhadap alam sekitarnya.

\section{Daftar Pustaka}

Abduh, Syekh Muhammad. tt. Tafsir Al-Mannar. Beirut Darul Ma'rifat. 
Kastolani, Ibadah Ritual Dalam Menanamkan Akhlak Remaja

Abdurrahman, Fadh bin Sulaiman al-Rumi. 1992. Konsep Salat Menurut al-Qur'an, Telaah Kritis Tentang Fiqh Salat, Alih Bahasa Abdullah Abbas, Firdaus, Jakarta

Ahmad, Imam. tt. Musnad Imam Ahmad bin Hanbal. Beirut: Dar Al-Kutub Al-'Ilmiyah

Ahmad, Khurshid. 1989. Prinsip-prinsip Pokok Islam. Jakarta: Rajawali Press.

Ahyadi, Abdul Aziz. 1987. Psikologi Agama Kepribadian Muslim Pancasila. Bandung: Sinar Baru,

Al-Ghozali, Imam. tt. Ihya' Ulumuddin 111. Singapura: Sulaiman Mar'i,

Al-Hafidz, Imam Abi Isa Muhammad bin Isa bin Surah At-Tirmidzi. tt. Sunan Tirmidzi. Beirut: Dar al-Fiqr.

Al-Yassu'i, Fr. Lois Ma'luf dan Bernard Tottel Al-Yassu'i. 1986. Al-Munjid. Beirut: Dar El-Machreq Sarl Publisen

Amin, Ahmad. 1975. Etika (Ilmu Akhlak). Jakarta: Bulan Bintang,

Anshari, Endang Saifuddin. 1992. Kuliah al-Islam. Jakarta: Rajawali Press.

Ash-Shiddieqy, Hasbi. 1983. Pedoman Shalat. Semarang: Pustaka Rizki Putra. .1954. Kuliah Ibadah. Jakarta: Bulan Bintang.

Basri, Hasan. 2000. Remaja Berkualitas. Yogyakarta: Pustaka Pelajar

Daradjat, Zakiah. 1980. Peranan Agama dalam Kesehatan Mental. Jakarta: Gunung Agung. 1993. Puasa Meningkatkan Kesehatan Mental. Jakarta: Ruhama. 1999. Dasar-Dasar Agama Islam. Bandung: Universitas Terbuka.

Djatnika, Rachmat. 1996. Sistem Etika Islami (Akhlak Mulia). Jakarta: Pustaka Panjimas.

Hakim, Atang Abd., dan Jaih Mubarok. 2000. Metodologi Studi Islam. Bandung: Remaja Rosdakarya.

Haneef, Suzane, 1979. Mengapa Memilih Islam. Bandung: Remaja Rosdakarya.

Hurlock, Elizabeth B. Child Development, Sixty Edition Internasional Students, Edition 146, Graw - Hill, Kogakusa, LTD

Kartono, Kartini.1989. Hygiene Mental dan Kesehatan Mental dalam Islam. Bandung: Mandar Maju.

Madjid, Nurcholish. 2000. Islam Doktrin dan Peradaban. Jakarta: Yayasan Wakaf Paramadima.

Muhaimin. 1994. Dimensi-dimensi Studi Islam. Surabaya: Karya Abditama. 
Inject, Interdisciplinary Journal of Communication, Vol. 1, No. 2, Desember 2016:127-144

Munawwir, Ahmad Warson. 1984. Al-Munawwir, Kamus Arab-Indonesia. Yogyakarta: Pondok Pesantren Al-Munawwir Krapyak.

Najati, Ustman. 1981. Al-Qur'an dan Ilmu Jiwa. Bandung: Balai Pustaka.

Nasution, Harun. 1985. Islam Ditinjau dari Berbagai Aspeknya. Jakarta: UI Press.

Rachim, Abdul dan Fathoni. 1987. Syariat Islam: Tafsir Ayat-Ayat Ibadah. Jakarta: Rajawali.

Rahmat, Jalaluddin. 1986. Islam Alternatif. Bandung: Mizan

Rasyid, Sulaiman. 2000. Fiqih Islam. Bandung: Sinar Baru Algesindo.

Razak, Nasruddin. 1993. Dienul Islam. Bandung: Al-Ma'arif.

Shabir, Muslich. 1981. Riyadlush Shalihin jilid I. Semarang: Toha Putra.

Sudarsono. 1994. Sepuluh Aspek Agama Islam. Jakarta: Rinaka Cipta. 1995. Kenakalan Remaja. Jakarta: Rineka Cipta

Ya'kub, Hamzah. 1993. Etika Islam. Bandung: Diponegoro.

Yusuf, Syamsu. 2000. Psikologi Perkembangan Anak dan Remaja. Bandung: Remaja Rosdakarya. 